\title{
Soluble Vascular Endothelial Growth Factor Receptor 2
}

National Cancer Institute

\section{Source}

National Cancer Institute. Soluble Vascular Endothelial Growth Factor Receptor 2. NCI

Thesaurus. Code C141267.

Soluble vascular endothelial growth factor receptor 2 is encoded by the human KDR gene. This protein may play a role as a decoy receptor for vascular endothelial growth factors (VEGF)-1, 2 and 3. 